\title{
ADVICE ABOUT INFANT FEEDING FOR ALLERGY PREVENTION - A CONFUSING PICTURE FOR AUSTRALIAN CONSUMERS?
}

Original Article

AUTHORS: Netting, M.J. ${ }^{1,2}$, Allen K.A. ${ }^{3}$

1 Healthy Mothers Babies and Children's Theme, South Australian Health Medical Research Institute, North Adelaide, Australia.

2 Discipline of Paediatrics, School of Medicine, The University of Adelaide, Adelaide, Australia.

3 Murdoch Children's Research Institute. The Royal Children's Hospital. 50 Flemington Road, Parkville 3052 Victoria

4 Corresponding Author: Dr Merryn J Netting. Healthy Mothers Babies and Children, South Australian Health Medical Research Institute, 72 King William St North Adelaide, Australia. Phone 618812 84403. Email: merryn.netting@sahmri.com

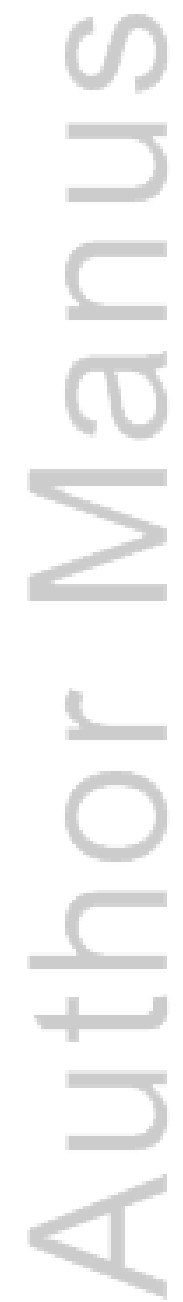

This is the author manuscript accepted for publication and has undergone full peer review but has not been through the copyediting, typesetting, pagination and proofreading process, which may lead to differences between this version and the Version of Record. Please cite this article as doi: $10.1111 /$ jpc.13594 


\section{ADVICE ABOUT INFANT FEEDING FOR ALLERGY PREVENTION - A CONFUSING PICTURE FOR AUSTRALIAN CONSUMERS?}

\section{ABSTRACT:}

Aim: Early feeding plays an important role in programming the immune system, particularly the risk of food allergy. There are many infant feeding guides published for consumers available in Australia, with most based on the NHMRC 2012 Infant Feeding Guidelines for Health Workers and the Australasian Society of Clinical Immunology and Allergy (ASCIA) Infant Feeding Advice for allergy prevention. We sought to compare allergy specific content of infant feeding educational material written for parents with these two documents.

Methods: Australian websites of children's hospitals, early child health organisations and consumer groups providing information about diet during pregnancy, breastfeeding and early infancy were compared with NHMRC and ASCIA guidelines.

Results: Twenty-five sets of infant feeding information were identified. Food allergy was discussed in 18 resources. Recommended length of exclusive breastfeeding and timing of commencing solid foods was consistently around 6 months, with some variation in wording. Advice regarding to include and not delay introduction of common allergens into babies' diets was generally consistent with NHMRC and ASCIA recommendations, however the audit identified some resources that still recommended delayed introduction of common allergens.

Conclusion: As consumers have access to a plethora of health information it is imperative that information about infant feeding from health care authorities is simple, evidence-based and consistent to avoid confusion. Use of consensus wording related to infant feeding guidelines to prevent allergies will provide clear messages related to the timing of introduction to solid foods and inclusion of allergens in the early diet.

\section{KEY WORDS:}

infant feeding, infant recommendations, timing of solids, breastfeeding and food allergy

\section{LEARNING POINTS:}

\section{What is already known on this topic:}

In Australia the NHMRC 2012 Infant Feeding Guidelines and the Australasian Society of Clinical Immunology and Allergy (ASCIA) provide infant feeding advice for allergy prevention. Many other infant feeding guides are also published for consumer use. 


\section{What this paper adds:}

While most infant feeding advice for consumers is consistent with NHMRC and ASCIA recommendations, some resources are out dated, still recommending delayed introduction of common allergens.

It is imperative that information about infant feeding from health care authorities is simple, evidence-based and consistent to avoid confusion.

\section{INTRODUCTION AND AIM:}

In Australia, food allergy is now relatively common amongst infants(1). There has been an increase in more serious clinical presentations of food allergy $(2,3)$, and increasing persistence of food allergy into secondary school and beyond $(4,5)$.

In Australia, dietary recommendations specifically aiming to reduce the risk of food allergy in children were included in the 2003 National Health and Medical Research Council (NHMRC) Infant Feeding Guidelines for Health Workers(6). These recommendations, directed at infants with a strong family history of allergies, were consistent with those of the American Academy of Paediatrics(7), and were based on outcomes of cohort studies. The guidelines advised allergen avoidance in the maternal diet during lactation, delayed introduction to solid foods and avoidance of common allergens in the infant's diet $(6,7)$. However, these strategies did not prevent the increasing incidence of food allergy and may in fact have been a contributing factor $(8,9)$. During the mid to late 2000s there was a sea change in recommendations related to the prevention of food allergy, both nationally and internationally as guidelines switched from delayed introduction of allergens to their timely introduction, when tolerated, in the infant diet in an effort to promote tolerance to the allergen (10-12). Since 2015 these recommendations have been strengthened by high-level evidence from several recent randomised controlled trials testing the effect of inclusion of common allergens in the infant's diet compared with complete avoidance on food allergy development (13-15). As a result there has been a call internationally to modify infant feeding guidelines to actively promote early inclusion of allergens (particularly peanut) into the infant diet (16).

The World Health Organisation (WHO) provides worldwide feeding advice and formulates global nutrition strategies designed to prevent malnutrition $(17,18)$. Australia's NHMRC is responsible for development of evidence-based Infant Feeding Guidelines: Information for Health Workers, last updated in 2012, and revised in 2015(19). Australian Guidelines related to prevention of food allergy have been led by the Australasian Society of Clinical Immunology \& Allergy (ASCIA) who published their first allergy prevention in children position statement in 2005 as a response to research-based evidence that delayed complementary feeding and prolonged avoidance of allergens (in maternal and infant 
diets) did not reduce incidence of food allergy (12). ASCIA released Infant Feeding Advice for consumers in 2008, (revised in 2010) recommending 1) breastfeeding with no maternal dietary exclusions and 2) introduction to solid foods from 4 to 6 months with no delay in inclusion of allergenic solid foods (20). The latest ASCIA May 2016 update introduced new advice for a broader range of allergenic foods, and have changed advice around timing of introduction to solid foods to align with the NHMRC. (21). Feeding advice from the WHO, NHMRC and ASCIA is summarised in Table 1.

A number of national organisations and all Australian state departments of health interpret the NHMRC and ASCIA infant feeding guidelines in order to develop consumer advice related to infant feeding. The aim of this audit was to identify the key sources and the specific content of Australian health education materials available on the internet providing infant feeding advice related to food allergy prevention and compare these against the NHMRC Infant Feeding Guidelines: Information for Health Workers (19) and ASCIA Infant Feeding Advice (21).

\section{METHODS:}

Australian websites providing information on diet during pregnancy, breastfeeding and early infancy were searched in March 2016 using the Google web browser. Websites targeted included those of children's hospitals in each Australian state, early child health organisations and consumer groups. We included policy documents and consumer-focussed information in the audit. No web-archived material was included in this audit. To identify information missed in the initial targeted search, an internet search was performed using the search terms 'allergy prevention', 'introduction to solid foods' and 'breastfeeding and allergies'.

The following was noted for all identified material: source, date published, type of organisation and type of information (policy or consumer education material). The information was classified into recommendations related to general feeding advice or allergy-specific advice. General advice included: recommended length of exclusive breastfeeding, timing of introduction to solid foods, and spacing of introduction to new foods. Allergy-specific advice included recommendations related to maternal diet, benefit of breastfeeding for allergy prevention, use of hydrolysed infant formula, timing and type of solid foods to be introduced, including advice related to the introduction of specific allergens. 


\section{RESULTS:}

Twenty-five sets of Australian infant feeding information were identified (Table 2). The sources of the feeding information were; Government organisations $(n=24)$; National organisations $(n=2)$; State-based organisations $(n=23)$ and non-government funded, not for profit organisations $(n=1)$. Although the search was conducted in 2016, dates on the material ranged from 2002 to 2015. Six of the identified sets of material were not dated.

Type of information: Of the 25 sets of infant feeding information, four policy documents were identified, 11 were websites, and 10 were consumer booklets or pamphlets available for download.

Recommendations related to exclusive breastfeeding: The wording used to recommend the length of exclusive breastfeeding was: 'for six months' ( $\mathrm{n}=4,16 \%$ ), 'up to / until six months' ( $\mathrm{n}=2$, $8 \%$ ), 'around / about six months' ( $\mathrm{n}=11,44 \%$ ) or 'until solid foods are started' ( $\mathrm{n}=1,4 \%)$. Recommendations to continue breastfeeding with solid foods were included in $n=11(44 \%)$ of the documents audited.

Timing of complementary foods: The wording related to timing of commencement of complementary foods varied from 'at 6 months' $(\mathrm{n}=4,16 \%)$, 'around / about six months' ( $\mathrm{n}=16$, 64\%), 'from six to seven months' ( $n=1,4 \%$ ), 'not before four months' ( $n=5,20 \%$ ), or 'when developmentally ready' $(n=2,8 \%)$. No organisations used the wording that complementary foods be started 'from four to 6 months'.

Spacing of new foods: Recommendations related to the spacing of introduction to new foods was as follows: 'slow introduction not necessary' ( $n=1,4 \%$ ), 'one new food at a time' ( $n=6,24 \%)$, 'every 2 to 3 days' ( $n=4,16 \%)$, 'after several or a few days' ( $n=4,16 \%)$.

Allergy related material: Food allergies were discussed within booklets or pamphlets providing general infant feeding advice $(n=14,56 \%)$, with four allergy-focussed pamphlets or web pages identified. Four of these 18 sets of advice identified common food allergens, and while common symptoms of a food allergy were described in two sources, only one source advised parents what to do if there was a reaction to food. None of the information reviewed provided advice specifically for infants with existing allergies.

Allergy prevention: Of the 18 resources that discussed allergy, the following advice was offered: Introduction of allergens; 'from 6 months' ( $n=1,4 \%$ ), 'do not avoid / delay allergens' ( $n=6,24 \%)$, 'delayed introduction' ( $n=5,20 \%$ ), 'use low allergen foods' ( $n=1,4 \%$ ), 'caution with allergens' ( $n=3$, $12 \%)$. Where timing of introduction of nut pastes was discussed, recommendations varied from 6 to 12 months. Where timing of introduction of egg was discussed, recommendations varied from 4 to 12 months. Maternal dietary advice to avoid peanut was given in two of the resources reviewed. No advice related to a maternal healthy diet was provided in any of the information audited. 


\section{DISCUSSION:}

Starting solid foods is an important milestone in infant development and early feeding experiences set up life long habits, influence nutritional status and have an important role in programming the immune system $(8,23)$. Consumers have access to a wealth of information related to infant feeding of varying scientific credibility. Information is included in the hand held child health records provided by each state and territory and feeding guides are produced by the major paediatric hospitals in each state. In addition there are many other sources of information related to infant feeding, particularly in the popular press and via the Internet.

The issues specific to prevention of allergy relate to timing of initiating complementary foods and which foods are introduced $(24,25)$. Timely inclusion of allergens, particularly peanut, in the infant diet, as opposed to delayed inclusion, significantly reduces the incidence of food allergy (13). Thus, it is important that there is simple, consistent messaging around guidelines related to infant feeding and prevention of food allergy. The results of this audit indicate that the opposite is the case, and allergy prevention advice for young families written by Australian health providers includes a diverse range and some times opposing recommendations, leading to a potential source of confusion for consumers. The main differences we identified related to the timing of starting solid foods, and advice related to the inclusion of allergens in the weaning diet.

Differences in the recommended age that infants should be started on solid foods identified in this audit are most likely related to the difference between the wording used between the WHO, NHMRC and ASCIA feeding guidelines. Internationally, there is general agreement that complementary feeding should not commence prior to 4 months of age, due to increased risk of obesity, gastrointestinal disorders and development of allergy $(11,26)$. The 2012 NHMRC guidelines recommend solid foods at 'around 6 months of age' and do not provide an age before which babies should not have solid foods. This was a change from the 2003 guidelines, which advised that solid foods should not be given 'before the age of 4 months' (6). The May 2016 ASCIA guidelines encouraged introduction to solid foods around 4 to 6 months of age, when the baby is showing signs of readiness, and the recent change to these guidelines may be the reason why they are not reflected in any of the educational material audited. While in reality there is probably little difference between the words 'at / around / when', there is confusion amongst consumers and health professionals alike. For example, the term 'at' may refer to the beginning of the sixth month (25 weeks of age), or at the completion of the month (28 weeks), a difference of four weeks. The intent of the WHO guidelines statement of 'at 6 months' is to prevent displacement of breastfeeding with low energy and nutrient dense foods in malnourished communities, but is also an active guideline to prevent very delayed introduction to solid foods beyond 6 months of age and consequential malnutrition (27). The most current Australian resource included in this audit used the term 'when 
your baby is ready', rather than giving a set age in the recommended time to start solid foods (28), and we consider that teaching parents of the developmental indicators that a baby is ready to start eating is a more developmentally appropriate approach to starting eating.

Recommendations regarding which 'first foods' to include in babies diets varied. Some of the resources audited provided prescriptive advice regarding the specific order of foods to introduce to babies. Although this gives parents a guide, it is an issue because it may set up feeding rules that do not matter. Nutritionally, the main gaps for young infants are for iron, and in some cases protein and energy. The NHMRC infant feeding guidelines state that 'As long as iron-rich foods are included in first foods, foods can be introduced in any order, and at a rate that suits the infant' and 'delaying the introduction of solid foods, including allergenic foods after the age of 6 months may increase the risk of developing allergic symptoms'. Most of the consumer advice audited was consistent with current ASCIA and NHMRC feeding advice, which advises to not delay introduction of allergens such as egg and peanut into a baby's diet. However, this audit uncovered infant feeding information for consumers advocating delayed allergen exposure - some of this information, dated 2002 may simply have not been taken down from a website, however it is still available for consumers to access.

There was little uptake of the (now out-dated) advice related to use of partially hydrolysed formula for non breastfed infants with a family history of food allergy in the audited material. This may be because the focus of most of the consumer information was on introduction to solid foods, rather than provision of information related to breast or formula feeding.

The infant feeding information audited included very little information regarding common food allergens, and signs and symptoms of food allergy. This may have been beyond the scope of some of the information material, however given the increasing prevalence of food allergy in the community inclusion of this information should be considered by authors of health education materials on infant feeding.

Possible reasons for the inconsistencies in the infant feeding information for consumers include inadequate staffing levels to review and update consumer information as there are changes to research evidence. There may be perceived differences between the WHO guidelines and NHMRC guidelines, specifically related to the 'at six months' compared with 'around 6 months' wording recommendation for the timing of starting solid foods, additionally the frequent updates to the ASCIA feeding guidelines may also have lead to confusion.

There is limited data on the timing of solid foods, and the types of foods that are offered to infants. Information gathered from the HealthNut cohort indicates that families in Victoria responded to the 2008 ASCIA change in feeding recommendations, with a reduction in the incidence of delayed introduction of solid foods egg and peanut $(1,29)$. However, participants with a family history of 
food allergy were more likely to delay the introduction of egg and peanut than families without a family history (29), indicating a higher perceived level of risk. These families are the very ones who are likely to benefit from earlier, rather than delayed introduction of allergens, particularly peanut (13), so it is important that messages are consistent and reach families of both high and low risk of developing food allergies.

\section{CONCLUSION}

In conclusion, this audit of consumer material showed that there is a diversity of advice related to infant feeding available to the Australian public, some of which is not consistent with current guidelines. Although wording may be slightly different about timing of introduction to solid foods, small differences in wording can lead to confusion. In the age of electronic media parents have quick and easy access to a plethora of information, and evidence-based information from health care authorities should say the same thing to minimise confusion amongst consumers. We believe that use of consensus-based wording related to infant feeding guidelines to prevent allergies would prevent confusion related to the timing of introduction to solid foods and inclusion of allergens such as egg and peanut in the early diet.

\section{Acknowledgments:}

This work was supported by funding from the National Health and Medical Research Council (NHMRC). The study sponsors had no involvement in the study design, collection, analysis and interpretation of data, writing of the report, or decision to submit the article for publication.

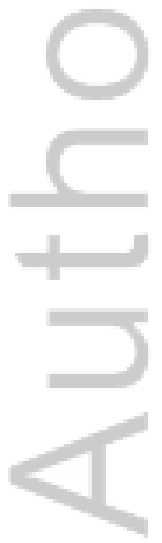


1. Osborne N, Gurrin L, Koplin J, et al. Prevalence of food challenge: Confirmed food allergies in a large pediatric population based study in Melbourne, Australia. Allergy. 2010;65:375.

2. Mullins RJ. Paediatric food allergy trends in a community-based specialist allergy practice, 1995-2006. The Medical Journal of Australia. 2007;186(12):618-21.

3. Mullins RJ, Dear KB, Tang ML. Time trends in Australian hospital anaphylaxis admissions in 19981999 to 2011-2012. The Journal of allergy and clinical immunology. 2015;136(2):367-75.

4. Savage JH, Matsui EC, Skripak JM, et al. The natural history of egg allergy. The Journal of allergy and clinical immunology. 2007;120(6):1413-7.

5. Loke P, Koplin J, Beck C, et al. Statewide prevalence of school children at risk of anaphylaxis and rate of adrenaline autoinjector activation in Victorian government schools, Australia. The Journal of allergy and clinical immunology. 2016;138(2):529-35.

6. NHMRC. Dietary Guidelines for Children and Adolescents in Australia. Canberra: National Health and Medical Research Council; 2003.

7. American Academy of Pediatrics. Committee on Nutrition. Hypoallergenic infant formulas. Pediatrics. 2000;106(2 Pt 1):346-9.

8. Prescott SL, Smith P, Tang M, et al. The importance of early complementary feeding in the development of oral tolerance: concerns and controversies. Pediatric Allergy and Immunology. 2008;19(5):375-80.

9. $\quad$ Palmer DJ, Prescott SL. Does early feeding promote development of oral tolerance? Current Allergy Asthma Reports. 2012;12(4):321-31.

10. Greer FR, Sicherer SH, Burks AW, et al. Effects of early nutritional interventions on the development of atopic disease in infants and children: the role of maternal dietary restriction, breastfeeding, timing of introduction of complementary foods, and hydrolyzed formulas. Pediatrics. 2008;121(1):183-91. 11. Agostoni C, Decsi T, Fewtrell M, et al. Complementary feeding: a commentary by the ESPGHAN Committee on Nutrition. Journal of Pediatric Gastroenterology and Nutrition. 2008;46(1):99-110.

12. Prescott SL, Tang ML, Australasian Society of Clinical Immunology and Allergy. The Australasian Society of Clinical Immunology and Allergy position statement: Summary of allergy prevention in children. The Medical Journal of Australia. 2005;182(9):464-7.

13. Du Toit G, Roberts G, Sayre PH, et al. Randomized trial of peanut consumption in infants at risk for peanut allergy. The New England journal of medicine. 2015;372(9):803-13.

14. Palmer DJ, Metcalfe J, Makrides M, et al. Early regular egg exposure in infants with eczema: A randomized controlled trial. The Journal of allergy and clinical immunology. 2013;132(2):387-92 e1.

15. Perkin MR, Logan K, Tseng A, et al. Randomized Trial of Introduction of Allergenic Foods in Breast-Fed Infants. The New England journal of medicine. 2016.

16. Fleischer DM, Sicherer S, Greenhawt M, et al. Consensus communication on early peanut introduction and the prevention of peanut allergy in high-risk infants. Journal of Allergy and Clinical Immunology. 2015;136(2):258-61.

17. UNICEF W. Global strategy for infant and young child feeding. Geneva, World Health Organization, 2003. . Geneva: World Health Organization; 2003.

18. WHO. Infant and young child feeding Fact Sheet $\mathrm{N}^{\circ} 342$ Updated January 2016. World Health Organization, 2016.

19. NHMRC. Infant Feeding Guidelines: Summary. Canberra: National Health and Medical Research Council; 2013.

20. Australasian Society of Clinical Immunology and Allergy. ASCIA Infant feeding advice. 2010.

21. Australasian Society of Clinical Immunology and Allergy. ASCIA Infant Feeding Advice

http:/ /www.allergy.org.au/health-professionals/papers/ascia-infant-feeding-advice2016 [

22. NHMRC. Infant Feeding Guidelines. Canberra: National Health and Medical Research Council;

2012.

23. WHO. Infant and young child feeding : model chapter for textbooks for medical students and allied health professionals. : World Health Organisation; 2009.

24. Grimshaw KE, Allen K, Edwards CA, et al. Infant feeding and allergy prevention: a review of current knowledge and recommendations. A EuroPrevall state of the art paper. Allergy. 2009;64(10):1407-16. 25. Koplin JJ, Allen KJ. Optimal timing for solids introduction - why are the guidelines always changing? Clinical and Experimental Allergy. 2013;43(8):826-34.

26. Sun C, Foskey RJ, Allen KJ, et al. The Impact of Timing of Introduction of Solids on Infant Body Mass Index. Journal of Pediatrics. 2016. 
27. Kuriyan R, Kurpad AV. Complementary feeding patterns in India. Nutrition, Metabolism and Cardiovascular Disease. 2012;22(10):799-805.

28. Raising Children Network (Australia) Ltd. Introducing Solids 2016 [Available from:

http://raisingchildren.net.au/articles/when to introduce solids.html.

29. Tey D, Allen KJ, Peters RL, et al. Population response to change in infant feeding guidelines for allergy prevention. The Journal of allergy and clinical immunology. 2014;133(2):476-84.

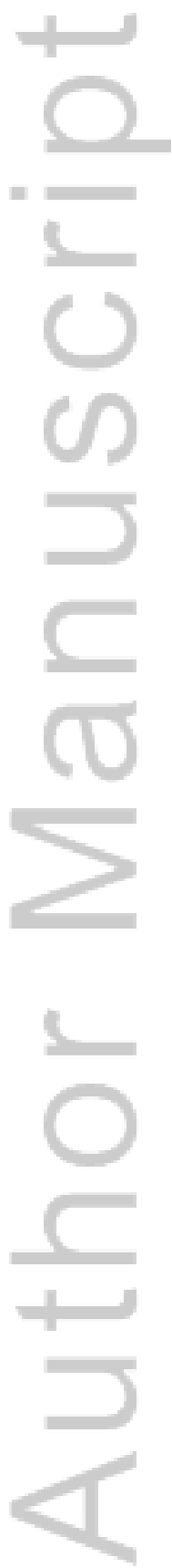

This article is protected by copyright. All rights reserved. 
TABLE 1. Summary Of Infant Feeding Advice Related To Food Allergy Prevention Produced by WHO, NHMRC AND ASCIA.

\begin{tabular}{|c|c|c|c|c|c|}
\hline \multicolumn{2}{|l|}{$=2$} & \multicolumn{4}{|c|}{ SUMMARY OF INFANT FEEDING ADVICE } \\
\hline & $\begin{array}{c}\text { WHO, } 2002 \text { \& 2016(17, } \\
18)\end{array}$ & NHMRC, 2003 (6) & $\begin{array}{c}\text { NHMRC, 2012, } \\
2015(22)\end{array}$ & ASCIA, 2010(20) & ASCIA, May 2016(21) \\
\hline Breastfeeding & $\begin{array}{l}\text { Exclusively, for first } 6 \\
\text { months }\end{array}$ & $\begin{array}{l}\text { Exclusively, until } 6 \\
\text { months }\end{array}$ & Until around 6 months & At least the first 6 months & At least the first 6 months \\
\hline $\begin{array}{l}\text { Continued } \\
\text { Breastfeeding }\end{array}$ & $\begin{array}{l}\text { Up to } 2 \text { years of age or } \\
\text { beyond. }\end{array}$ & $\begin{array}{l}\text { Until } 12 \text { months and } \\
\text { beyond }\end{array}$ & $\begin{array}{l}\text { Until } 12 \text { months and } \\
\text { beyond. }\end{array}$ & $\begin{array}{l}\text { For as long as mother and } \\
\text { infant wish to continue. }\end{array}$ & $\begin{array}{l}\text { For as long as mother and } \\
\text { infant wish to continue. }\end{array}$ \\
\hline Breast Milk Substitutes & & Standard infant formula & Standard infant formula & $\begin{array}{l}\text { Partially hydrolysed 'HA' } \\
\text { formula }\end{array}$ & $\begin{array}{l}\text { Standard cow's milk based } \\
\text { formula }\end{array}$ \\
\hline Solid Foods - Timing & At 6 months & $\begin{array}{l}\text { 6-7 months (if needed } \\
\text { earlier, not before } 4 \\
\text { months) }\end{array}$ & Around 6 months & From around $4-6$ months & $\begin{array}{l}\text { When your infant is ready, } \\
\text { at around } 6 \text { months, not } \\
\text { before } 4 \text { months }\end{array}$ \\
\hline $\begin{array}{l}\text { First Foods to } \\
\text { Introduce }\end{array}$ & $\begin{array}{l}\text { Use fortified } \\
\text { complementary foods or } \\
\text { vitamin-mineral } \\
\text { supplements as needed. }\end{array}$ & $\begin{array}{l}\text { Gluten-free cereals (e.g. } \\
\text { rice), then add other } \\
\text { foods such as vegetable } \\
\text { and fruit, and well cooked } \\
\text { pureed liver and meat }\end{array}$ & $\begin{array}{l}\text { Iron-containing nutritious } \\
\text { foods }\end{array}$ & $\begin{array}{l}\text {...according to what the } \\
\text { family usually eats } \\
\text { (regardless of whether the } \\
\text { food is thought to be highly } \\
\text { allergenic). }\end{array}$ & $\begin{array}{l}\text {... according to what the } \\
\text { family usually eats, } \\
\text { regardless of whether the } \\
\text { food is considered to be a } \\
\text { common allergen }\end{array}$ \\
\hline First Foods to Avoid & & $\begin{array}{l}\text { Honey, tea, nuts } \\
\text { (choking), fruit juices and } \\
\text { reduced fat milks }\end{array}$ & $\begin{array}{l}\text { Whole nuts and other } \\
\text { hard foods (choking). } \\
\text { Avoid sugar, honey, juice, } \\
\text { high levels of saturated } \\
\text { fat, added salt (health) }\end{array}$ & & \\
\hline $\begin{array}{l}\text { Advice Regarding } \\
\text { Common Food } \\
\text { Allergens }\end{array}$ & & $\begin{array}{l}\text { If there is a strong history } \\
\text { of family allergy, } \\
\text { introduction of cheese, } \\
\text { yoghurt, ice- cream, fish } \\
\text { and wheat cereal should } \\
\text { be delayed until } 12 \\
\text { months of age. If there is } \\
\text { a strong history of peanut } \\
\text { allergy, peanut products } \\
\text { (including peanut butter) } \\
\text { should be avoided until } \\
\text { after } 3 \text { years of age }\end{array}$ & $\begin{array}{l}\text { No evidence that delaying } \\
\text { the introduction of solid } \\
\text { foods beyond around } 6 \\
\text { months reduces the risk } \\
\text { of allergy. } \\
\text { "Delaying the } \\
\text { introduction of solid } \\
\text { foods, including allergenic } \\
\text { foods, after the age of } 6 \\
\text { months may increase the } \\
\text { risk of developing allergic } \\
\text { symptoms" (p87) }\end{array}$ & $\begin{array}{l}\text { Insufficient evidence to } \\
\text { support previous advice to } \\
\text { delay or avoid potentially } \\
\text { allergenic foods (such as } \\
\text { egg, peanuts, nuts, wheat, } \\
\text { cow's milk and fish) for the } \\
\text { prevention of food allergy } \\
\text { or eczema. }\end{array}$ & $\begin{array}{l}\text { Some evidence that } \\
\text { introduction of common } \\
\text { allergic foods (including } \\
\text { cooked egg as raw egg is } \\
\text { not recommended, } \\
\text { peanuts, nuts, wheat, fish) } \\
\text { should not be delayed. }\end{array}$ \\
\hline
\end{tabular}

This article is protected by copyright. All rights reserved. 


\begin{tabular}{|c|c|c|c|c|c|}
\hline Peanuts & & From 3 years of age & $\begin{array}{l}\text { "...Evidence now } \\
\text { supports treating peanuts } \\
\text { the same as any other } \\
\text { foods and introducing } \\
\text { them at around } 6 \text { months } \\
\text { of age (assuming that } \\
\text { peanut is fed in a suitable } \\
\text { physical form, such as a } \\
\text { paste, and not as the } \\
\text { whole nut)" (p91) }\end{array}$ & & $<12$ months \\
\hline 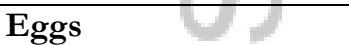 & & & & & Before 8 months \\
\hline Spacing of New Foods & $\begin{array}{l}\text { Start with small amounts } \\
\text { and gradually increase. } \\
\text { Increase consistency and } \\
\text { variety. }\end{array}$ & $\begin{array}{l}\text { New foods should be } \\
\text { offered no more often } \\
\text { than each five to } 10 \text { days }\end{array}$ & $\begin{array}{l}\text { Foods can be introduced } \\
\text { in any order and at a rate } \\
\text { that suits the infant }\end{array}$ & One new food at a time & $\begin{array}{l}\text { Parents may wish to give } \\
\text { one new food at a time }\end{array}$ \\
\hline Maternal Diet & & $\begin{array}{l}\text { If there is a family history } \\
\text { of peanut allergy } \\
\text { breastfeeding mothers } \\
\text { should avoid peanuts }\end{array}$ & $\begin{array}{l}\text { There is no evidence that } \\
\text { avoiding any particular } \\
\text { foods or food allergens } \\
\text { during pregnancy, } \\
\text { lactation or infancy } \\
\text { provides any benefit in } \\
\text { preventing allergy, and } \\
\text { this is no longer } \\
\text { recommended" (p82) }\end{array}$ & $\begin{array}{l}\text { Exclusion of allergenic } \\
\text { foods from the maternal } \\
\text { diet has not been shown to } \\
\text { prevent allergies. }\end{array}$ & $\begin{array}{l}\text { Balanced diet, rich in } \\
\text { fibre, vegetables and fruit. } \\
\text { Oily fish } 3 \text { times a week. }\end{array}$ \\
\hline
\end{tabular}

This article is protected by copyright. All rights reserved. 
TABLE 2: RESULTS OF AUDIT OF AUSTRALIAN INFANT FEEDING ADVICE N (\%)

\begin{tabular}{|c|c|}
\hline \multicolumn{2}{|c|}{ Authorship and Date of Publication } \\
\hline State or National Organisation & 23 State / 2 National $(n=25)$ \\
\hline Government Funded Organisation (Yes / No) & 24 - Government, 1 non Government \\
\hline Date of publication & 2002 to 2015.6 were not dated \\
\hline \multicolumn{2}{|c|}{ Type of information } \\
\hline Policy or guideline & $4(16 \%)$ \\
\hline Website & $11(44 \%)$ \\
\hline Consumer booklet or pamphlet & $10(40 \%)$ \\
\hline \multicolumn{2}{|c|}{ Recommendations related to exclusive breastfeeding } \\
\hline For six months & $4(16 \%)$ \\
\hline Up to / until 6 months & $2(8 \%)$ \\
\hline Around / about six months & $11(44 \%)$ \\
\hline Until solid foods are started & $1(4 \%)$ \\
\hline Continue breastfeeding with solids & $11(44 \%)$ \\
\hline \multicolumn{2}{|c|}{ Timing of introduction to solid foods } \\
\hline At six months & $4(16 \%)$ \\
\hline Around / about six months & $16(64 \%)$ \\
\hline From four to six months & $0(0 \%)$ \\
\hline From six to seven months & $1(4 \%)$ \\
\hline Not before four months & $5(20 \%)$ \\
\hline When developmentally ready & $2(8 \%)$ \\
\hline \multicolumn{2}{|c|}{ Spacing of new foods } \\
\hline Slow introduction not necessary & $1(4 \%)$ \\
\hline One new food at a time & $6(24 \%)$ \\
\hline Every 2-3 days & $4(16 \%)$ \\
\hline After several or a few days & $4(16 \%)$ \\
\hline \multicolumn{2}{|c|}{ Food allergy specific advice } \\
\hline Mentioned within generic booklet / pamphlet & $14(56 \%)$ \\
\hline Allergy focused pamphlet / webpage & $4(16 \%)$ \\
\hline Identification of common allergens & $4(16 \%)$ \\
\hline Description of common symptoms & $2(8 \%)$ \\
\hline What to do if there is a reaction & $1(4 \%)$ \\
\hline Advice for infants with existing allergies & $0(0 \%)$ \\
\hline \multicolumn{2}{|c|}{ Allergy prevention advice } \\
\hline \multicolumn{2}{|l|}{ Breastfeeding Statements } \\
\hline - No effect & $0(0 \%)$ \\
\hline - Preventative (lower risk) & $7(28 \%)$ \\
\hline Hydrolysed formula & $1(4 \%)$ \\
\hline \multicolumn{2}{|l|}{ Timing of Complementary Foods } \\
\hline Avoid early (before 4 months) & $5(20 \%)$ \\
\hline Avoid starting too late & $5(20 \%)$ \\
\hline Discuss with Doctor if family history of allergy & $4(16 \%)$ \\
\hline Eczema as a risk for food allergy & $1(4 \%)$ \\
\hline Refer to ASCIA website & $3(12 \%)$ \\
\hline \multicolumn{2}{|l|}{ Introduction of Allergens } \\
\hline From 6 months & $1(4 \%)$ \\
\hline - $\quad$ Do not avoid / delay allergens & $6(24 \%)$ \\
\hline - $\quad$ Delayed introduction of allergens & $5(20 \%)$ \\
\hline - $\quad$ Use low allergen foods & $1(4 \%)$ \\
\hline - $\quad$ Caution with allergens & $3(12 \%)$ \\
\hline Introduction of nut pastes (months) & 6 to 12 months \\
\hline Introduction of egg (months) & 4 to 12 months \\
\hline Maternal dietary advice (avoid peanut) & $2(8 \%)$ \\
\hline Maternal healthy diet & $0(0 \%)$ \\
\hline
\end{tabular}




\section{University Library}

\section{- M M N E R VA A gateway to Melbourne's research publications}

Minerva Access is the Institutional Repository of The University of Melbourne

Author/s:

Netting, MJ;Allen, KJ

Title:

Advice about infant feeding for allergy prevention: A confusing picture for Australian consumers?

Date:

2017-09-01

Citation:

Netting, M. J. \& Allen, K. J. (2017). Advice about infant feeding for allergy prevention: A confusing picture for Australian consumers?. JOURNAL OF PAEDIATRICS AND CHILD HEALTH, 53 (9), pp.870-875. https://doi.org/10.1111/jpc.13594.

Persistent Link:

http://hdl.handle.net/11343/293017 